\title{
A primeira das virtudes: justiça e reformismo ilustrado na América portuguesa face à espanhola
}

\author{
Andréa SLEMIAN \\ Universidade Federal de São Paulo (Brasil) \\ slemian@unifesp.br
}

Recepción: 17 de enero de 2014 / Revisión: 20 de marzo de 2014

Aceptación: 5 de mayo de 2014 / Publicación: diciembre de 2014

\section{RESUMO}

O presente artigo tem como objetivo analisar as medidas propostas pelos reformismos ilustrados ibéricos para a justiça na América, em especial aquelas dedicadas a garantir um melhor funcionamento dos tribunais e um controle para imparcialidade dos pleitos. Tendo o português como foco, parte-se da compreensão que o mundo ibero-americano teve um pano de fundo comum, presente na tradição jurídico política compartilhada pelas monarquias que, de caráter jurisdicional, corporativa e católica, emigraria para América e imporia alguns limites à realização dos projetos reformistas ibéricos no tocante a uma mais eficaz e "racional" aplicação da justiça então em voga.

Palavras-chaves: Justiça, instituições, juízes, América ibérica, reformismo, século XVIII.

\section{The First of the Virtues: Justice and Enlightened Reformism in Portuguese and Spanish America}

\begin{abstract}
This objective of this article is to analyze proposals for judicial reform in America within the context of Iberian Enlightened Reformism and, particularly, measures designed to ensure the improved functioning of the courts and the impartiality of the trials. Focusing on the Portuguese case, the study is based on the understanding that the Ibero-American world had a common background, reflected in a shared legal and political tradition of a jurisdictional, corporative and Catholic nature, that was to be transmitted to America and imposed its limits on the execution of the then-in-vogue Iberian reform projects for a more effective and "rational" administration of Justice.
\end{abstract}

Keywords: Justice, Institutions, Judges, Iberian America, Reformism, $18^{\text {th }}$ century.

Sumario: 1. Introdução. 2. Os limites do(s) reformismo(s) ilustrado(s). 3. As reformas e a "justiça dos juízes”. 4. Conclusão. 5. Referências bibliográficas. 


\section{INTRODUÇÃO}

É por demais conhecido como os "espanhóis americanos" se levantaram contra as medidas da monarquia bourbônica nas décadas da segunda metade do século XVIII, comumente tratadas como o momento dos reformismos ilustrados, no sentido de substitui-los por "peninsulares" nos altos postos da administração colonial. É igualmente sabido hoje que tal processo deve ser pensado tendo em conta a alta participação dos crioulos nestas esferas desde o século XVI, mesmo o amplo espaço de autonomia e poder que estes grupos possuíam nas instituições que se transladaram pelo oceano numa lógica jurídica corporativa e tradicional, sem o qual a criação de uma sociedade aos moldes das ibéricas (pois que obviamente o mesmo vale para os portugueses), seria impensável. O que deve ser levado em conta para que não nos deixemos seduzir pelo axioma de que então teriam sido eles sistematicamente excluídos de cargos vitais, tomando como nosso o discurso que muitos de seus setores construiriam nestas décadas e que acabaria servindo como pano de fundo para as interpretações que durante muito tempo ligaram, de maneira simplista, o reformismo às Independências numa chave de injustiça metropolitana contra seus "fiéis vassalos"1.

Sem dúvida, a evidente politização que impregnou este discurso foi uma marca da época referida. Um dos seus exemplos mais contundentes está na representação redigida pelo cabildo da cidade do México, em 1771, diante do conhecimento de informes que desaconselhavam a elevação de "americanos" para altos postos de administração e governo no Novo Mundo². Segundo suas palavras, esta ação estaria "atropellando tantas razones de equidad, de justicia, de utilidad y necesidad pública, y aun de el honor y gloria de la monarquia" pela qual os "espanhóis americanos" teriam se distinguido "com facultades o empleos", não merecendo "que se ensangriente en su cabeza la espada de la justicia" 3 . A contundência dos termos e sua difusão era a expressão de um discurso reivindicatório que, em nome da tradição, articulava os interesses e pretensões dos crioulos como direitos radicados na ordem jurídica existente. No caso especial dos juízes, que nos interessa mais especialmente nestas páginas, a defesa de seu maior conhecimento da terra e dos seus costumes servia de grosso argumento para o bom desempenho dos jurisprudentes americanos nos pleitos. O que respondia à dita política bourbônica que, mesmo sem ser monolítica, procurara nomear maior número de magistrados europeus, e mesmo deslocar da localidade de origem a ação judicial de outros, como ficaria evidente em ações da coroa em relação às Audiências, e mesmo no controle da venda dos cargos ${ }^{4}$.

A princípio, reações da mesma natureza e contundência por parte dos "portugueses americanos", sob a evocação de direitos adquiridos para sua preferência no exercício

\footnotetext{
1 A bibliografia é amplíssima e remonta aos próprios coevos, cabendo destacar a obra de LYNCH, 2001, como um exemplo da longevidade desta interpretação. Mas a crítica a ela também já possui, ao menos, algumas décadas, ver: CAMPBELL, 1972.

2 "Representación que hizo la Ciudad de México al rey don Carlos III en 1771 sobre que los criollos deben ser preferidos a los europeos en la distribución de empleos y beneficios de estos reinos". Edição de HERNÁNDEZ y DÁvalos, 2007. Ver: Elliot, 2006, pp. 472-475, e, em especial, a análise de Garriga, 2014.

3 Ibidem, p. 27 e 39.

4 Burkholder, 1972; Garriga, 2013.
} 
dos cargos e ofícios (prelação), não são correlatos nos domínios lusos. Se tomarmos como base de comparação a estrutura judicial, é fato que enquanto se observava o declínio da presença crioula na magistratura das Audiências, no Brasil ocorreria quase o oposto com os oriundos da terra nos tribunais da Relação, resultado do maior número de estudantes americanos egressos dos bancos da Universidade de Coimbra a partir do século XVIII ${ }^{5}$. Mas algumas questões devem ser evocadas para o entendimento do que se apresenta, primeiramente, como um descompasso. Antes de tudo, o das temporalidades dos processos de colonização em ambas as Américas, sendo sabido como a monarquia espanhola investiu mais pesadamente desde seu início, retroalimentada pelos metais preciosos e seu poderio econômico, enquanto Portugal, até então muito voltado para o "império da pimenta" na Índia, somente olharia com olhos muito mais atentos para suas terras a partir do deslanche da produção açucareira e, sobretudo, com a Restauração a partir de 1640. Dessa forma, a instalação de instituições que, nos domínios espanhóis, pautariam a vida administrativa colonial ocorre já nas primeiras décadas do Quinhentos, como se vê o caso das Audiências. Estas, que seriam peças fundamentais no translado e reprodução do padrão de sociedade corporativa e jurisdicional vigente no reino de Castela, bem como elementos centrais do governo das novas terras, já existiam no número de onze no século XVI, sendo instaladas mais três até fins do século XVIII ${ }^{6}$. A participação dos crioulos nos seus postos fora, desde sempre, muito comum, haja vista a existência de universidades em muitos de seus vice-reinos, e mesmo a prática comum de venda do exercício dos ofícios, sobretudo ao que dizia respeito aos ofícios vários que não apenas de juízes ${ }^{7}$.

Com papel em escala jamais comparável às Audiências, os Tribunais da Relação na América portuguesa tiveram um desenvolvimento mais tímido. O primeiro foi o da cidade de Salvador na Bahia, instalado em 1609, exatamente no momento de união das duas coroas ibéricas sob domínio dos Filipes ${ }^{8}$. Nesse sentido, a experiência de governo na vizinha espanhola não fora mero acaso para seu estabelecimento e mesmo definição de suas atribuições. Ele deixaria de funcionar em 1626, momento de grande instabilidade política, parte em função dos conflitos e tensões geradas pelas investidas flamengas na cidade, e sua ocupação de Pernambuco a partir de 1630. Mas foi restabelecido em 1652, e seria o único a funcionar na América portuguesa até meados do século XVIII -apenas com possibilidade de recursos conduzidos à Lisboa- quando o desenvolvimento do Centro-Sul do Brasil, também em função da descoberta de ouro nas Minas Gerais, colocou a necessidade de um maior controle real, desdobrada igualmente na instalação de uma Relação no Rio de Janeiro, em 1755. Assim, se na América espanhola faz sentido a politização que se fez às medidas da coroa de maior controle de cargos, na portuguesa presenciava-se nesse momento um

\footnotetext{
5 Wehling, 2004, p. 341.

6 Foram elas: a de Santo Domingo (1526), Nueva España (1527), Panamá (1538, restabelecida em 1563), Guatemala (1542, restabelecida em 1568), Lima (1542), Santa Fé (1547), Nueva Galicia (1548), Charcas (1555/1561), Quito (1563, restabelecida em 1720), Chile (1567, restabelecida em 1605/1609), Manila (1583, restabelecida em 1595), Buenos Aires (1661, restabelecida em 1782), Cuzco (1787) e Caracas (1786). GARrigA, 2010, p. 236.

7 Ver, ao menos: StumpF - Chaturvedula, 2012.

8 Schwartz, 1979.
} 
maior adensamento da malha judicial, inexistente com ampla abrangência territorial anteriormente, menos ainda com significativa participação dos "filhos da terra" ". Já foi igualmente ressaltado pela historiografia que, em termos comparativos e ao longo dos séculos de colonização, os portugueses reinóis tanto emigrariam em muito maior número que os espanhóis peninsulares, como ocupariam predominantemente postos e cargos no Novo Mundo num padrão jamais ocorrido na América espanhola ${ }^{10}$.

No entanto, a perspectiva comparativa, mais precisamente "conectada" ou integradora dos processos na América ibérica, nos permite propor aqui, em uma síntese não exaustiva e sequer totalmente inovadora, formas de compreensão de uma das dimensões de suas histórias comuns ${ }^{11}$. Nesse sentido, defendemos que, mesmo com formas e ritmos distintos, como se pode visualizar a partir dos dados citados e bem conhecidos, a chave para entendimento da justiça e as medidas propostas para sua reforma na América, tanto espanhola como portuguesa, tiveram um pano de fundo comum (falamos precisamos dos governos de Carlos III e IV, entre 1759 e 1808, e D. José e de D. Maria, entre 1750 e 1808). Estava este na tradição jurídico política compartilhada pelas monarquias ibéricas que, de caráter jurisdicional, corporativa e católica, emigraria para América e imporia alguns limites à realização dos projetos reformistas ibéricos no tocante a uma mais eficaz e "racional" aplicação da justiça então pretendida. Mais ainda, que as medidas tomadas durante estas décadas mantiveram o "modus operandi" judicial das monarquias ibéricas no que dizia respeito às garantias de justiça e à prática da jurisprudência que continuaram centrados na figura do juiz e na sua ação de interpretação da norma/lei ${ }^{12}$.

Ainda que tenhamos como moldura geral a realidade ibero-americana, trataremos especificamente aqui do caso português que, como cada uma das partes dessa imensidão dos domínios ibéricos no Novo Mundo, será analisada na sua conjuntura específica tendo em vista uma estrutura jurídica comum que forneceu lastro ao desenvolvimento da administração e do governo aos moldes dos peninsulares sem maiores alterações desde o século XV que as propostas a partir da segunda metade do Setecentos. Por mais que este processo tenha gerado uma expressiva politização em ambas as Américas, e sua compreensão como parte de uma crise nos paradigmas políticos das antigas monarquias tenha gerado uma vigorosa e profícua vertente historiográfica $^{13}$, é sua dimensão jurídica, mais especificamente judicial, que destacaremos. Defender-se-á que esta manteria seu caráter tradicional diante do fato do programa reformista não alterar, e sequer pretender, a base de funcionamento das monarquias, como desenvolveremos a seguir. Assim, se politicamente se percebem contundentes críticas aos governos, diagnósticos de sua ineficácia, propostas e projetos de reformulação -efeitos que caberia atribuir à própria crise-, a resposta a ela no tocante à justiça estaria na evidente reafirmação das práticas existentes.

\footnotetext{
9 Wehling, 2004; Camarinhas, 2010.

10 Confere destacado por Monteiro, 2009b, a partir das trajetórias das elites ibéricas como uma das chaves para se entender como um correlato ao termo identitário "crioullo" jamais existiu com tamanha circunscrição e amplitude para caso português.

11 Pimenta, 2007.

12 Central aqui é a análise de Garriga, 2013 para o mundo espanhol, a qual estendemos ao português.

13 Halperin Donghi, 1985; Novais, 1986; Jancsó - Pimenta, 2000.
} 


\section{OS LIMITES DO(S) REFORMISMO(S) ILUSTRADO(S)}

Em ensaio de D. Rodrigo de Sousa Coutinho -posteriormente, eminente secretário de Estado da Marinha e Domínios Ultramarinos (nomeado em 1796), um dos responsáveis pela política que levaria a Família real portuguesa à América- escrito quando estava ele em missão diplomática em Turim, a descrição do funcionamento da magistratura na Sardenha era portadora de uma visível intenção de servir de exemplo à política portuguesa ${ }^{14}$. Encontrado apenas na sua tradução para o francês, com anotações de punho do autor, o texto afirmava logo no início que:

Dans touts les États de S.M. le Roi de Sardagne la jurisdiction contentieuse est entirèrement séparée de tous les autres objets d'administration: le juge, le préfet, et le sénateur, ou membre des tribunaux superièreurs, est purement dévoué à la décision des procès civils et criminels, et sa jurisdiction ne s' etend pas à aucun objet de finances, ou même à quelque autre partie de l'administration des États ${ }^{15}$.

A proposição, aparentemente banal e comum para nós hoje, da separação entre as esferas contenciosas (de justiça) da administração (governo), tanto não era uma realidade, como sua imbricação representava o cerne de funcionamento das monarquias ibéricas até então. Nesse sentido, se algo caracterizava o mundo do Antigo Regime, era a concepção de que todo ato de poder era eminentemente jurisdicional: possuir "iurisdictio" (esta era a palavra), ou seja, jurisdição, era ter o poder de estabelecer o que era de direito, de resolução de conflitos, ao fim das contas, de ditar a justiça (papel primordialmente do rei, por este delegado a seus vassalos). Obviamente que nem todos os cargos e ofícios possuíam jurisdição (e as ações de governo e de justiça, ainda que entrelaçadas, não eram irredutíveis uma à outra), mas todo ato administrativo podia ser judicialmente contestado recorrendo-se a alguma autoridade jurisprudente, qual seja, a de juízes ou de magistrados, nos seus mais variados níveis. O papel destes era, portanto, central nessa ordem tradicional, tanto para o bom desempenho dos responsáveis pelo governo (por vezes, os próprios juízes) como na interpretação do que deveria valer como direito ${ }^{16}$.

Não à toa, nas páginas seguintes ao citado ensaio sobre a Sardenha, D. Rodrigo tratava da ação dos juízes - a citação é longa, mas quase fala por si mesma:

Sur les matières purement civiles, il [o regime] a défendu dans les premières lois de son Code au magistrat d'interpréter jamais la loi, et on proscrivait tout autre sens que celui qui offre naturellement le sens des mots avec lesquels la loi est conçue; il y joignit une précaution fort sage, $\mathrm{c}^{\prime}$ est de laisser au magistrat la liberté de demander au souverain l'interprétation de la loi, lorsque le sens n'est pas clair ou pourrait être sujet à des grands inconvénients. Ainsi le souverain lia sagement les mains des magistrats et empêcha que le pouvoir législatif se trouvât concentre dans les mêmes mains avec

\footnotetext{
14 Essai sur la magistrature, sur la forme des procès, et sur la legislation des États de S.M. lei Roi de Sardaigne..., em Silva, 1993, t. 1, pp. 192-204.

15 Ibidem, p. 193.

16 Vallejo - Varela, 2012; Hespanha, 1994; Cardim, 2008; Garriga, 2013.
} 
l'exécutif, évitant par là um grand nombre d'abus qui s'éprouvent dans d'autres pays, où l'on voit dériver de pareille source um Droit incertain etdes lois contradictoires ${ }^{17}$.

Ao apontar que não se deixaria aos magistrados a interpretação da lei, e mesmo que caberia ao soberano a dissolução das dúvidas nos casos em que elas não estivessem claras, para se evitar a "incerteza" e "leis contraditórias", D. Rodrigo valorizava o modelo que ia mesmo de encontro à tradição portuguesa (e mesmo ibérica). Escrito às vésperas da Revolução Francesa, que teria como um de seus projetos mais radicais o da submissão da magistratura a um sistema de leis definidas pela nação, e mesmo de sua retirada da decisão sobre assuntos de governo (base para criação do que se conceberia como "contencioso administrativo"), as questões estavam na ordem do dia. Projetos estes que somente puderam ser concebidos mediante a valorização e identificação dos espaços de representação legislativa com o papel virtuoso de traduzir a "vontade geral", com a faculdade de criar a lei -e, portanto, estabelecer o que seria o direito-, além de interpretá-la, o que os revolucionários franceses levariam ao limite. O ambiente de politização da crítica aos juízes e magistrados, identificados com o monarca despótico, corruptelas e vícios, e a jurisprudência como um saber hermético e degenerado, chegaria nesse momento ao seu ápice ${ }^{18}$.

Sem dúvida que algumas destas questões já estavam presentes desde os chamados reformismos ilustrados, ambiente no qual D. Rodrigo havia sido formado e do qual é considerado um dos seus mais expressivos expoentes. E apesar de ser um equívoco toma-los como precursores do que viria a se consolidar posteriormente (no caso das Américas, as Independências), os impasses então colocados são fundamentais para se entender como, no caso ibero-americano, lidar-se-ia com a presente tradição jurídica existente. Isso porque, mesmo com a profusão de estudos e abordagens históricas e historiográficas acerca do seu significado, e o salutar questionamento acerca da possibilidade ou não de se falar em unidade (ou unidades) para as medidas tomadas e projetadas pelas monarquias bourbônicas e bragantinas no período, qualquer tentativa de reformulação de práticas de administração e justiça implicaria tocar no funcionamento tradicional do seu governo ${ }^{19}$.

Com toda sua diversidade, poderíamos resumir os intentos de racionalização e de melhor funcionamento das instituições e autoridades régias, em especial na América, em uma visível intenção de fortalecimento do governo como atividade independentemente da justiça, exatamente nos moldes como destacara D. Rodrigo. O que se traduziu na proposição de diversos mecanismos disciplinadores e regulamentadores que interferissem em vários aspectos da vida, criando normas, procedimentos e orientações através da via administrativa, que não dependessem, a princípio, da esfera contenciosa para seu andamento (como uma separação mais radical entre uma

17 Essai sur la magistrature..., p. 197.

18 Clavero, 1997; Hespanha, 1998; Frate, 2005; Krynen, 2009.

19 A bibliografia é imensa e diversa, mas cabe ressaltar as interpretações que enxergam, até pouco, que o reformismo na América teria sido uma brutal ruptura: BRADING, 1990; LyNCH, 2001; ElLIOT, 2006; as quais tem sido cada vez mais contestadas por visões que matizaram seu alcance, ou mesmo que a negaram: MAXWELL, 1995; Fradera, 2005; Monteiro, 2009a; Ruiz Torres, 2011. Para uma síntese atual de posições: Paquete, 2009. Seguimos para a questão: Garriga - Slemian, 2013. 
administração "executiva" e outra "jurisdicional") 20. Daí a profusão de medidas, bem como a criação de novos órgãos e agentes, que visavam uma melhor organização fiscal, fazendária, comercial, territorial, o desenvolvimento de gêneros, culturas e indústrias, etc., concomitantemente à profusão de projetos, memórias, ensaios para introdução de novos métodos científicos, reflexão sobre novas teorias, melhorias das instituições, aprimoramento da educação e da então "civilização das gentes" em todo mundo ibero-americano ${ }^{21}$.

As reações conflitivas que algumas de suas políticas teriam ocasionado já são também por demais sabidas pela historiografia. Afinal, por mais que se deva tomar com cautela a ideia de que muitas de suas medidas tivessem como escopo uma maior centralização da ação das metrópoles, é fato que na sua base estava presente uma tentativa de reforço da ação do governo, do poder de "polícia" em sentido coevo ${ }^{22}$. Cautela diante da própria natureza pluralista das monarquias ibero-americanas que, conjuntamente à sua característica jurisdicional, permitiam amplo espaço de autonomia aos que governavam em nome do rei, bem como asseguravam, de uma maneira ou de outra, o reconhecimento dos direitos das suas partes (reinos, vice-reinos e corporações). Padrão este que foi igualmente transportado para a América, mas cuja dinâmica não deve ser unicamente entendida como sinônimo de uma total independência destes territórios em relação à Castela e Portugal, mas igualmente tendo em vista as relações de interdependência que pautavam a imposição da tradição jurídica ibérica à sociedade colonial, marcadamente multiétnica ${ }^{23}$.

Sem adentramos nesta questão - com o que fugiríamos de nosso tema-, o importante é salientar que o mesmo esforço reformista vinha no sentido de fortalecer o papel legislativo do soberano, aliado à valorização do direito pátrio que deveria ser, a partir de então, tido como prioritário perante a grande diversidade de fontes e de direitos existentes (pluralismo jurídico). É isso que se vê nas medidas que pretenderam a reforma das universidades (especialmente as de Coimbra e Salamanca) e da ciência da jurisprudência, marcadas pela tentativa de desvalorização do direito romano e das fontes doutrinais vinculadas à tradição medieval, bem como da diminuição do espaço de interpretação do juiz, o que caracterizava o cerne do funcionamento do Antigo Regime $^{24}$. Para o ideal reformista "a melhor lei [...] he a que menos deixa ao arbítrio

\footnotetext{
20 SubTiL, 2011. Veja-se como Pedro Rodríguez de Campomanes, o emblemático ministro da Fazenda do primeiro governo de Carlos III, demonstrava ter plena consciência da dificuldade e gravidade da separação entre os assuntos governativos e contenciosos: "Quando se trata de dominio, posesion, de conservación de honores, de imposición de penas, en una palavra de derecho de tercero, para causarle perjuicio con la sentencia 'es necesaria la audiencia ordinária', y substanciación de los autos. La razón es clara, porque cada parte ha de probar los hechos, en que funda su intención: 'ésta no se puede liquidar sin trámites contenciosos'. Pero si se trata de favorecer la labranza, dexando á los dueños y cultivadores de las tierras todo aquel arbítrio, que cada uno tiene para sacar de su terreno el mejor partido posible, cerrando, cercando, plantando, aprovechando etc. 'Son reglas necesarias y comunes, que penden tan solamente de la instrucción de los que mandan', y no necesitan, si saben su oficio, más que insinuación, ó representación, ú oportunidad, que dé impulso á las providencias". (Apud GARRIGA, 2009, p. 63).

21 Para uma síntese dos projetos e intentos de mudança: Chiaramonte, 1979; Novais, 1986.

22 SubTiL, 2011, cap. 11.

23 A questão da compreensão do direito "colonial" alimenta um atual debate de posições, para o qual ver, ao menos: Hespanha, 2001; Souza, 2006; Clavero, 2012.

24 Alonso Romero, 2010; AraúJo, 2002.
} 
do Juiz: o melhor Juiz he o que menos deixa ao seu próprio arbítrio", conforme sintetizaria anos depois o tratadista José Inácio da Rocha Peniz na defesa da mais estrita vinculação do juiz à lei ${ }^{25}$.

Mas razões há para se falar nos limites, e mesmo na inexistência de absoluta coesão, das propostas reformistas para toda América ibérica. De maneira geral, cabe destacar que o intento de reforço da atividade governativa pretendido desde meados do século XVIII dificilmente prescindiu da sua dimensão jurídica. São por demais conhecidas as funções extrajudicias, administrativas e políticas, que possuíam juízes e magistrados nas Américas, papel já destacado para o caso das Audiências, mas igualmente visível para os Tribunais da Relação. Nestes últimos, além dos assuntos contenciosos ordinários, os desembargadores eram igualmente verdadeiros instrumentos da política real, responsáveis pela resolução de conflitos interinstitucionais, fiscalização sobre a administração de aldeias, minas, bens eclesiásticos, alfândega, contrabando, etc., também com funções investigativas como repressivas, funcionando, segundo Wehling, como um "braço executivo do governo" ${ }^{26}$. Sendo assim, era visível no Brasil, em fins do século XVIII, o acúmulo de cargos pelos desembargadores tanto pelo adensamento da malha judicial como pela escala das medidas pensadas para administração.

E como já demonstrado acima, as preocupações de D. Rodrigo iam de encontro a essa ampla ação. Veja-se como, em resposta a uma consulta régia acerca da utilidade da superintendência das Alfândegas, um desembargador que ocupara seu posto por mais de doze anos, argumentava acerca do fundamental papel que os mesmos magistrados aí desempenhavam na administração:

Tendo por fim a Instituição dois lugares de Magistrados manter seguros debaixo da proteção das Leis a liberdade civil, e política, que sofre a Constituição de qualquer Estado, e os Direitos de propriedade, e segurança; são por extremo uteis os Ministros da Justiça. A seria administração della, o cuidado de vigiar sobre a segurança pública, prevenir os Crimes, punilos quando se violão as Leis, e conservar a polícia no seio da paz publica; deveres são da maior importância, que eles exercitão em nome dos Soberanos ${ }^{27}$.

Mas seu argumento ia no sentido de marcar que, sendo "essencial nas Monarquias" que o "Poder Judiciario esteja separado do Legislativo, e Executivo", este papel deveria ser diretamente exercido por seus "Delegados", desde que fiscalizados por eles, os desembargadores. Pois seria "em nome do Soberano" que "os Magistrados executão as Leis, cuidão na sua aplicação, e fazem manter a publica tranquilidade." Sua intenção era clara e seguia a mesma chave tradicional: a função executiva de governo deveria ser reforçada, desde que mantida aos dotados de jurisdição sua avaliação.

\footnotetext{
25 Da influencia do foro sobre a felicidade pública. Oração inaugural recitada a 12 de outubro de 1807. Coimbra, Real Imprensa da Universidade, 1808. Apud BARBAS HomEM, 2003, p. 606.

26 Wehling, 2004, p. 359.

27 (Sin título). Documento 2, Lisboa, s/d (cerca fins XVIII), fl. 1-1v. Arquivo Nacional da Torre do Tombo [en adelante AN/TT], Ministério do Reino, Maço 493.
} 
Neste sentido, a citada proposta evidencia como as novas soluções não deveriam abalar os alicerces do regime jurídico existente, jurisdicional e pluralista. A historiografia sobre o reformismo espanhol tem aberto caminho para que se pense nestes termos no que toca às suas implicações na justiça, ao escancarar como o modo de funcionamento da monarquia e suas consequentes estratégias patrimonialistas, colocaram limites internos à execução de algumas políticas, e mesmo reforçaram o caráter tradicional do governo ${ }^{28}$. Vejamos dois exemplos para o caso português, cujas soluções visivelmente investiram na criação de novas esferas de jurisdição, ao contrário de diminuí-las, em nome de uma maior eficácia da ação real.

Este foi o caso das soluções contenciosas que serviriam à Junta de Comércio, órgão criada sob a égide do Marquês do Pombal em 1755 sob a justificativa de conter os abusos praticados pelos homens de negócio ao "real serviço" e ao "interesse público dos meus vassalos", e com uma clara intenção de maior regulamentação das práticas dos negociantes, nesse sentido emblemática do caráter das medidas ilustradas em $\operatorname{voga}^{29}$. Cabia à Junta igualmente o juízo acerca das causas contenciosas em que os autores ou réus fossem parte deste "corpo" mercantil, bem como delitos dos "descaminhos dos Meus Reais direitos e contrabandos". Mas, no ano seguinte instituía-se, na Casa da Suplicação (tribunal máximo recursal em Portugal), o cargo de Juiz Conservador para o Comércio, o qual teria "jurisdição privativa, e exclusiva de todas e quaisquer outras jurisdições" que servissem ao "bem comum" dessa atividade, sendo ocupado por um dos seus desembargadore ${ }^{30}$ Logo ampliou-se o espectro de atuação deste mesmo Juiz para os negócios dos falidos sob a afirmação de ser necessário "em algumas circunstâncias, conhecer-se com averiguação, e exame maior, que o "extrajudicial" (grifos nossos) ${ }^{31}$. Em função do acúmulo de funções do mesmo, em 1771, ordenou-se a sua extinção e criação de três novos magistrados para substituí-lo: o primeiro, o "Superintendente Geral dos Contrabandos"; o segundo, responsável pelos negócios dos falidos; e o terceiro, denominado Juiz Conservador dos "Privilegiados" 32 . Este último trataria das causas cíveis que ocorreriam entre os "negociantes da Junta do Comércio", e de tudo que for concernente à "observância dos seus respectivos privilégios" - e assim seguiriam existindo no século XIX. Dessa forma, o percurso de criação e funcionamento deste juízo evidencia que, se houve uma busca por uma maior eficácia da potestas pública no comércio, as fórmulas pensadas para tanto recorriam a modelos tradicionais de funcionamento do governo, o da criação de

28 Garriga, 2013; Ruiz Torres, 2011. Veja-se o caso das intendências criadas para a América espanhola que BRADING, 1990, p. 408, encarou como peça central da "revolução" no governo ao afirmar que elas incorporavam as "ambições administrativas e intervencionistas do Estado Bourbon"; posição que há muito já pode ser matizada pela análise de PietschmanN, 1996; e devidamente confrontada por FraderA, 2005, cap. 2, ao marcar a não dissolução das formas de administração jurídico-política da monarquia espanhola com os reformas ilustradas.

29 Decreto de 30-IX-1755. Ver: Pedreira, 1995; Chaves, s/d.

30 Alvará de 13-XI-1756. CollecÇAO...1830, p. 447. A justificativa era que, por um lado, estavam extintos os "cônsules" (juízes privativos) que anteriormente faziam esse papel, recaindo ele atualmente nas mãos do provedor e dos deputados da Junta de Comércio; por outro, as "grandes ruínas de cabedais e créditos" que se observava nas praças comerciais portuguesas em função dos enganos e das dilações a que estavam submetidos seus negócios, colocando em xeque a "boa fé" necessária à sua atividade.

31 Alvará de 30-V-1759. ColleCÇAO...1830, p. 661-662; Lopes, 2007.

32 Alvará de 16-XII-1771. ColleCÇAO...1829, p. 573. 
espaços jurisdicionais contenciosos aos quais caberia a fiscalização judicial das ações (o caso dos contrabandos é, sem dúvida, o mais evidente nesse sentido).

Talvez um dos exemplos mais contundentes para os impasses apontados seja o caso das Juntas de Administração e Arrecadação da Real Fazenda, criadas nos domínios ultramarinos a partir da instauração em Portugal do Erário Régio (1761), com o intuito de centralizar as atividades de administração e arrecadação dos rendimentos da Real Fazenda ${ }^{33}$. Especificamente, elas deveriam "gerir os rendimentos régios e promover sua arrecadação através da arrematação e fiscalização dos contratos”, mas o que nos interessa aqui é o arranjo geral que se pretendeu em matéria financeira. Com a criação do Erário, perderia o Conselho de Fazenda o "governo econômico" das finanças, que passaria ao primeiro, sendo que o segundo ganhava forma exclusivamente como instância judicial ${ }^{34}$. Só isso já nos diz muita coisa, já que as ações do Erário poderiam ser judicialmente questionadas pelo reformulado Conselho, o que não impediria que o órgão tivesse autonomia de ação em relação à própria coroa. No ultramar, ambas as funções não seriam distintas, e as Juntas teriam também as atribuições jurídicas da administração fazendária, sejam as de natureza voluntária (sobre questões que envolvessem a matéria) ou contenciosa, e acabariam funcionando como um importante fórum de poder e decisão (o que, sem dúvida, coloca à prova os intentos de sua compreensão como ação de caráter centralizador). Logo que as Juntas foram instituídas (em 1765) já causariam dúvidas sobre sua natureza, encaminhadas ao então governador da Bahia, Marquês do Lavradio. Em linhas gerais, questionavase se seria sua natureza administrar e arrecadar os rendimentos ou exercer o papel de um tribunal, o que se chocaria com o cargo dos antigos provedores, bem como dos existentes órgãos da Casa da Fazenda, Contos, Moeda, Alfândega. A resposta não tardou a vir em alvará de 1771 que extinguiu o dito cargo de provedor, bem como incorporou a Casa da Fazenda à Junta, que assumiria toda a jurisdição contenciosa e voluntária ${ }^{35}$. Era assim que a medida, por mais que pudesse ser vista como um esforço para racionalizar as instituições existentes e evitar conflitos de jurisdição, recriava a lógica existente de funcionamento de instituições mantendo bem intrincados administração e jurisdição.

O fato dos alicerces de um tradicional governo da justiça não serem abalados no seu cerne não nega a ampla experimentação de soluções em vários níveis, bem como seus projetos e projeções, não obstante circunscreve-os nesse ambiente de impasses ${ }^{36}$. A questão fica ainda mais evidente quando se trata especialmente da administração da justiça. Nesse sentido, a crítica corrente aos abusos praticados pelos tribunais, às corruptelas que envolviam magistrados e juízes, à demora dos pleitos, etc. tendia a ser enquadrada, sobretudo, como uma questão de incumprimento da lei. O que estava por detrás do reforço reformista na realização de visitas aos tribunais americanos -es-

\footnotetext{
33 Aqui seguimos Chaves, 2013.

34 O Conselho da Fazenda foi criado por carta régia de 22-XII-1761, mesmo dia da criação do Erário Régio.

35 Alvará de 3-III-1770 (Apud Chaves, 2013, p.89) que extinguia o Conselho da Fazenda na Bahia e o cargo de Provedor-mor "como se nunca houvesse existido".

36 Subtil, 2008; Ruiz Torres, 2011.
} 
pecialmente pelos espanhóis-, cuja finalidade García de León y Pizarro deixava claro ao encabeçar uma comissão com este objetivo, em 1777, para Quito:

siendo el principal objeto de la visita de esta Real Audiencia y tribunales de justicia restablecer a su antiguo ser las leyes y ordenanzas que por negligencia o malicia de los sujetos contra quienes se dirigen se hallan en el todo o en parte abolidas por su inobservancia ${ }^{37}$.

O problema central era o "restabelecimento" das antigas leis e ordenanças; sendo estas perfeitas, corruptíveis seriam os homens ${ }^{38}$. O que continuaria sendo a base em que se operava para uma reta justiça, conforme se verá a seguir.

\section{AS REFORMAS E A “JUSTIÇA DOS JUÍZES”}

O astuto D. Rodrigo não deixava escapar, no seu já citado ensaio, um ponto então considerado vital para o bom desempenho da magistratura: o da formação de seus quadros. Mas nesse quesito seu tom era de lamento, pois afirmava criticamente que na Sardenha a educação dos juízes estava longe de encorajar os talentos, não havendo " $n$ 'a d'autre encouragement à faire le bien que celui de la vertu" ${ }^{39}$. Novamente ele mostrava sua faceta extremamente crítica aos modelos vigentes ao enfatizar que seria apenas, e infelizmente, pela virtude que se teria um bom juiz.

Ora, toda a tradição jurídica moderna, responsável pela construção de uma ampla e difundida literatura acerca do que se concebia como um protótipo do bom julgador, ou do "judex perfectus", estava, ao fim e ao cabo, baseada na ideia moral de um indivíduo virtuoso ${ }^{40}$. Conforme já destacamos acima, os que possuíam função de julgar -ou seja, jurisdição- eram centrais no funcionamento da sociedade e do seu governo, e assim representavam o papel mais primordial do próprio soberano que era o de fazer a justiça e manter o equilíbrio social. Desde fins do medievo, consolidariam-se não poucas formas de expressão de arquétipo de juiz, as quais mostrariam ter longevidade. Na Casa da Suplicação, encontrava-se muito tardiamente a reprodução do capítulo LX ("das virtudes que se requerem a um bom julgador") do "Leal Conselheiro" de D. Duarte -conhecido como "o Eloquente", que reinaria entre os anos de 1433-1438-, que continua a servir de literatura aos desembargadores ${ }^{41}$. Segundo ele, seriam estes os requisitos para um bom julgar: o conhecimento (obrigação de saber discernir as causas), imparcialidade (obrigação de estar despojado de toda a paixão), justiça e equidade (obrigação de dar as tenções nos processos e agir com zelo e sem

37 Apud Garriga, 2013, p. 49.

38 Outro exemplo está em Garriga - Slemian, 2013, p. 199-200: "Um texto tão característico do pensamento reformista como o Nuevo sistema de gobierno económico de Campillo y Cossío (1789), não deixa lugar a dúvidas: para a reforma do governo político 'no se necesita mas que reducir las cosas á su primitivo instituto en los mas de los puntos, quitando los abusos, que ha introducido el tiempo; y proporcionando nuestro sistema al estado presente de las cosas, segun el tiempo en que vivimos".

39 "Essai sur la magistrature, sur la forme des procès,...", p. 195.

40 Garriga, 2006; Barbas Homem, 2003.

41 Barbas Homem, 2003, p. 66. 
favor $)^{42}$. Não faltavam evocações do "amor à Deus" em todo mundo ibérico, base para que o neogranadino Gabriel Alvarez de Velasco, jesuíta nascido em Bogotá e autor de um tratado monumental sobre os juízes perfeitos profusamente utilizado na literatura jurídica portuguesa (seiscentista e setencentista), apresentasse um longo requerimento das qualidades que devem ter os magistrados:

Beleza viriginal, aspecto veemente e formidável, atento, nem humilde nem atroz; mas com a dignidade de uma certa austeridade; grave; santo; severo; incorrupto, não adulável; contra os ímprobos; impiedoso para os criminosos; inexorável, altivo, árduo; potente em força e em majestade; terrível na verdade e a equidade; estudioso ${ }^{43}$.

Já no XVIII, Luís António Verney, no seu célebre Verdadeiro Método de Estudar, escrito sob os auspícios das Luzes, dizia que o bom juiz deveria ser capaz de resolver as causas com diligência, e mesmo que destacasse que sua sabedoria incluiria o conhecimento dos "princípios dos negócios comuns", da economia, das razões de fato dos negócios da vida civil, da história do reino, da política, da eloquência. Mas, em primeiro lugar, ele deveria possuir "temor à Deus, amor da verdade, desinteresse, boa doutrina e boa lógica". ${ }^{44} \mathrm{O}$ que era correlato à fala de $\mathrm{D}$. Antonio de Porlier, um magistrado canário de larga experiência americana que, nos últimos anos da mesma centúria, falava do que cabia aos magistrados como presidente do Conselho de Índias, em 1797:

El primero y grande precepto del amor a Dios es el centro á donde van á parar las líneas de todos los demás que comprehende la ley. En este único, como en raíz, se contiene[n] todos ${ }^{45}$.

Desse modo, nesse universo marcado pelo pluralismo jurídico, onde mais importante do que as leis -como seria posteriormente projetado pelos regimes constitucionais no século XIX adentro- era a ação dos juízes e sua interpretação dos casos de acordo com o saber dos doutos e os vários conjuntos de direitos existentes, resguardar uma boa justiça era, portanto, colocar imposições às pessoas dos próprios juízes. Mesmo concedendo-se uma distinção entre sua pessoa privada (de pai, esposo, amigo) e pública (esta investida de jurisdição), e sendo a separação entre ambas impossível de se alcançar para garantia das decisões, um conjunto de regras acabava prescrevendo sanções para impedir o uso de seu ofício em causa própria. Um exemplo era o da proibição dos casamentos com mulheres sob sua jurisdição, tal qual previsto nas Ordenações Filipinas, de 1603:

Por muitos inconvenientes, que se seguem de os Julgadores temporaes casarem com molheres de sua jurisdição, durando o tempo de suas Judicaturas, e ser o sobredito

42 Leal Conselheiro, 1842, p. 329, cap. LIX: Das virtudes que se requerem a huû boo julgador.

43 Judex Perfectus seu de Judice Perfecto Christo Jesu Domine Nostro Unique Perfectu, vivorum et mortuorum Judici dedicatus (1662). Texto original de A. Gellii. Noctivm Atticarvm libri XX, XIV, 4. Apud Barbas Homem, 2003, p. 598.

44 Barbas Homem, 2003, p. 604.

45 Apud Garriga - Slemian, 2013, p. 193. 
muito contra o serviço de Deus e nosso, e boa administração da justiça, querendo nisso prover, mandamos que os Corregedores das comarcas, Provedores, Ouvidores dos Mestrados, Ouvidores dos Senhores das terras, e os Juizes de fora das cidades, villas e lugares de nossos Reinos e Senhorios, durado o tempo de seus Offícios, não casem per palavras de presente sem nossa licença com molheres dos lugares, ou Comarcas, em que forem Julgadores, nem com molheres, que nas ditas Comarcas stêm com tenção de nelas morar ${ }^{46}$.

O temoroso era que o casamento enraizasse as relações do dito juiz e não lhe garantisse autonomia suficiente para o ato do julgar. Por esta razão, estava igualmente previsto nas mesmas Ordenações, que fossem punidos os julgadores que dormissem com mulheres que demandam, e mesmo que não recebessem, nem eles nem seus filhos, qualquer tipo de "dádivas" ou "presentes" (Livro 5, títulos XX e LXXI), entre outros delitos. Reforçava-se a necessidade de uma vida respeitosa, proba e com um saudável isolamento social conforme pregavam os doutrinadores, o que muitas vezes se refletia em uma série de privilégios (como significativas gratificações, isenções de impostos e mesmo certos privilégios processuais que impediam que fossem tomados como réus) em nome da garantia da imparcialidade.

É verdade que não era incomum encontrarmos referências à magistrados envolvidos em negócios e com a política local desde sempre, sendo eles predominantemente crioulos até o século XVIII nas áreas espanholas, mas igualmente entre a maioria dos reinóis na América portuguesa ${ }^{47}$. O que não deve ser visto, devido à mencionada impossibilidade de separação total entre as duas pessoas dos juízes, apenas como um permanente incumprimento das normas por parte da magistratura, como se aquelas para nada servissem. O significativo a destacar aqui nos parece ser a forma permanente de imposição de um padrão de comportamento aos juízes, sobretudo porque este não se alteraria na segunda metade do século XVIII. Ao contrário, seria ele reforçado pelos políticos ilustrados, num visível reconhecimento que o problema era a ação dos indivíduos na diagnosticada má administração da justiça.

Nesse sentido, é emblemática tanto a visita do espanhol José António de Areche à Audiência de Lima, imbuído do ideal ilustrado de melhoria funcionamento das instituições, bem como o relatório por ele produzido em 1778; em que não deixou de acusar vários de seus ministros de ações ilícitas que conduziam à ampla parcialidade nos julgamentos. Era contundente em afirmar que:

aquellos Tribunales y Ministros, que situados en las regiones más remotas y apartadas ven con igual distancia el premio y el castigo: se van insensiblemente olvidando de aquellos modelos de pureza e integridad [...] subrogando en lugar de estas justas ideas las que les va sujiriendo el Universal, continuo, y pernicioso mal exemplo, hijo de la opulencia, y de las costumbres de los Países en que viven, suelen venir a desamparar sus más sagradas obligaciones para prestarse á unas máximas propias sólo del interés

\footnotetext{
46 Ordenações Filipinas, Livro I, Título XCV, p. 233.

47 Schwartz, 1979, p. 65; Wehling, 2004, p.289.
} 
particular de un Hombre privado, pero agenas y extrañas de las Virtudes Políticas y Morales que deben adornar a un Ministro público ${ }^{48}$.

Segundo ele, o afastamento dos magistrados dos princípios e virtudes acabaria sendo a causa de todos os males. O relatório de Areche serviu de base para condenação de alguns deles e, ainda que esta tenha sido mais branda do que a proposta por ele, uma das soluções foi um maior envio de magistrados espanhóis para a citada Audiência ${ }^{49}$. Nesse caso, se na Espanha até poderia vir a ser considerada positiva a valorização da naturalidade para os cargos e ofícios, identificada com um sentimento de "amor à pátria", na América, o ter nascido na localidade passaria a ser concebido, cada vez mais, como um sinal de suspeita ${ }^{50}$.

Ainda que, conforme apontado, este escopo de soluções não tenha sido aplicado na América portuguesa, existiu uma preocupação por parte da coroa em acentuar, na segunda metade do XVIII, recomendações para que os magistrados não se dedicassem direta ou indiretamente à atividades comerciais, bem como que restringissem suas relações pessoais nas localidades em que estivessem servindo ${ }^{51}$. Mas uma questão era fato: quando pudessem ser comprovados os bons serviços do juiz, sua adesão à ordem e ao monarca, impedimentos legais, e também condenações, poderiam ser revertidos. No caso dos casamentos com mulheres da terra, conforme diziam as Ordenações inclusive, a coroa poderia vir a autorizá-las mediante solicitação. Exatamente o que aconteceu com o desembargador da Relação do Rio de Janeiro, Ignácio da Cunha de Thoar, cavaleiro professo da Ordem de Cristo, ao solicitar autorização para contrair matrimonio, "com pessoas de limpo sangue e honesto procedimento, apesar das proibições em vigor ${ }^{52}$. O que lhe foi concedido pelo Conselho Ultramarino.

$\mathrm{O}$ que nos leva à lógicas das correições, na qual um dos dispositivos centrais em todo mundo ibérico e ibero-americano eram os conhecidos juízos de residência. Em linhas gerais, consistiam estes na avaliação sobre a atuação de um juiz (ou mesmo de um governante) durante o tempo em que exercera um cargo numa determinada jurisdição, mediante o recolhimento de informações retiradas após seu término. Ou seja, um instrumento que tinha também por objetivo fazer efetiva a garantia moral do magistrado, mediante o controle e a disciplina de seu comportamento, pelo qual the poderia vir a ser cobrada responsabilidade por seus atos. Procedimento introduzido em Castela desde as medievais Partidas, mas de origem bem mais antiga com base no ius commune, parece plausível admitir que a introdução e funcionamento deste instituto em Portugal tivesse inspiração castelhana ${ }^{53}$. Este procedimento já se encontrava nas Ordenações Manuelinas (de 1521) portuguesas sob a justificativa:

\footnotetext{
48 Apud Garriga, 2013, p. 47-48.

49 Burkholder, 1972, p. 404. Segundo ele, em 1779 o número de espanhóis superaria o de "crioulos" na Audiência de Lima, sendo que até cinco anos antes se passava exatamente o contrário.

50 Garriga, 2013.

51 Wehling, 2004, cap. 15.

52 Requerimemto do desembargador da Relação do Rio de Janeiro, Inácio da Cunha de Thoar. Arquivo Histórico Ultramarino [en adelante AHU]. Lisboa, s/d (anterior a 1756). Rio de Janeiro, Caixa 59, doc. 106.

53 Ver, ao menos, Gonzalez Alonso, 2000 e 1978; Garriga, 1997; Barbas Homem, p. 671.
} 
E porque os Julgadores, e outros Officiaes da Justiça nom tomem atrevimento para usarem de seus Officios como non devem, Mandamos a todo los Juizes das Cidades, Villas, e Lugares de Nossos Reynos, e Senhorios, que do dia que começarem a servir seus Officios a dez dias primeiros seguintes começem tirar inquirições devassas sobre os Juizes que ante elles foram ${ }^{54}$.

As inquirições deveriam ser tiradas levando em conta todos os delitos que pudessem vir a atacar o princípio do bom julgamento, entre os quais tinham destaque os que "deixaram de fazer dereito por temor, peita, amor, odio ou negrigencia" ou recebessem "dadivas", por si mesmo ou por seus familiares.

Mesmo que algumas informações indiquem que o uso dos juízos de residências teria começado a decair progressivamente nas Audiências americanas no XVII ${ }^{55}$, e que em Portugal teria havido uma crescente burocratização dos mesmos com uma certa "previsibilidade" dos procedimentos administrativos no século XVIII ${ }^{56}$, tudo indica que seu papel de disciplinamento do corpo de magistrados continuaria a pautar os problemas que envolviam a justiça. Percebe-se, por um lado, a existência de uma tentativa de reforço de sua eficácia no lado lusitano, como demonstra um alvará de 1775 que denunciava uma situação de corrupção generalizada no seu funcionamento e determinava caber ao monarca escolher o bacharel que faria as residências, a partir de nomes propostos pela Mesa do Desembargo do Paço e pela Casa da Suplicação, impedindo que fosse apenas o presidente da primeira que nomeasse os sindicantes ${ }^{57}$. Por outro, uma preocupação, em plenas Luzes, comum à literatura jurídica, de que as inspeções aos magistrados não deveriam ser excessivamente exigentes, tampouco tão escrupulosas $^{58}$. Tomando-as em conjunto, pode-se imaginar a existência de impasses que as análises fixadas essencialmente na punição ou não dos envolvidos, no topos do "incumprimento" das normas e leis, ou das retaliações realizadas pelos próprios pares, tendem a relegar como marginal, mas que devem ser enquadradas na chave da reprodução de um padrão de juiz que os mesmos reformistas tenderam a reforçar: "limpo de mãos", "servo de Deus" e "obedientes às leis e ao soberano" 59 . Ao mesmo tempo, de defesa da "corporação" dos juízes, em meio à disseminação da crítica aos mesmos com mais afinco nos Setecentos. Dois exemplos de casos da Relação do Rio de Janeiro nos induzem a valorizar esta dimensão.

O primeiro, de 1759, trata-se de uma residência tirada pelo ouvidor geral do crime, o desembargador João Pedro de Sousa Sequeira Ferraz, pelos serviços prestados pelo bacharel Antônio de Matos e Silva, enquanto juiz de fora da cidade, acusado de "falta

54 OrdenaÇões manUelinas, Livro I, titulo XLIV, pp. 290-291.

55 Gómez GonzÁlez, 2012, p. 148.

56 CAmarinhas, 2012, p. 166, é um dos poucos trabalhos, juntamente com Barbas Homem, que se dedicam à temática no caso português, sendo sua análise feita assumidamente sobre uma amostragem da documentação existente.

57 Barbas Homem, 2003, p. 677.

58 Castillo de Bobadilla, autor que gozava de muito prestígio entre os portugueses, chegaria a defender no seu célebre Politica para corrigidores, o inconveniente de se praticarem investigações tão detalhadas como as praticadas nas residências, e mesmo sua substituição por um sistema de larga consulta pública aos administrados. Apud Barbas Homem, 2003, p. 691.

59 Garriga, 1997. 
de obesirvança à Ley de Vossa Magestade respectivas aos Indios" ${ }^{60}$. Os autos são longuíssimos, com várias testemunhas, e a conclusão do desembargador realmente $o$ inocenta: afirma que "cumpriu o sindicado as obrigações do ditto Logar, sendo bom letrado, pronto no despacho, limpo de mãos e bem procedido", e que não teria "violado" as ditas leis em razão dos índios terem juiz privativo no ouvidor da Comarca. Do que se vê que mais valia sua jurisdição e padrão de comportamento que o cumprimento das normas, as quais evidentemente não valiam para todos. O segundo caso, de 1757, é ainda mais eloquente acerca do disciplinamento que envolvia este ato de correição. Diante das acusações feitas à João Vieira de Andrade de que, no exercício do cargo de juiz de fora e também no de juiz de defuntos e ausentes, teria comerciado contra às leis, um acordão da Relação o acusa a pagar multa ${ }^{61}$. Diante de um requerimento do acusado tratando das "incivilidades" com que o juiz sindicante o teria tratado, bem como negando que dita sindicância teria realmente sido realizada, um parecer feito na Relação após sua condenação conclui: é melhor condená-lo para que fique "salve [a]o Suplicante o regresso contra quem legitimamente se provar que foi causa delas". Ou seja, mantinha-se o sentido da disciplina deixando ao suplicante a possibilidade de vir a buscar seu ressarcimento por via judicial contra o beneficiário, desde que ficassem provadas suas causas.

Na tradição do ius commune, havia também dois instrumentos jurídicos, mais precisamente vinculados ao processo, concebidos como formas de se garantir um bom julgamento que eram a recusação e a apelação ${ }^{62}$. Amplamente difundidos na cultura jurídica ibérica, possuíam eles um sentido complementar: a primeira deveria ser evocada antes das sentenças e a, segunda, posteriormente, em função de um mau julgamento (ou seja, de injustiça). A recusa estava prevista para todos os casos em que se pudesse vislumbrar que o juiz em questão tivesse relações (de parentesco, de interesses, de negócios, etc.) com qualquer uma das partes do processo, as quais poderiam recorrer à ela para sua substituição em nome da imparcialidade. A apelação, por sua vez, fez parte da evolução das formas antigas de recursos, e se consubstanciaria num instrumento para corrigir as sentenças injustas e exigir responsabilidade pelos danos indevidamente causados pelo juiz no exercício do seu ofício, por meio de sua anulação. A exigência desta última possuía, portanto, uma relação ontológica entre a exposição de virtudes de um modelo de juiz, e a exposição de seus vícios e pecados ${ }^{63}$. $\mathrm{Na}$ sua origem, ambas somente poderiam ser entendidas na distinção entre a pessoa pública-pessoa privada, pois se tratava de, antes de tudo, de impedir que a potestade de fazer justiça conferida ao magistrado fosse usurpada "em causa própria". Dessa forma, estavam baseadas na concepção tradicional de que era o juiz a peça chave da aplicação da justiça, cabendo criar instrumentos que cerceassem sua ação.

Mesmo que as formas de recusação e da apelação/responsabilidade dos juízes fossem diferentemente regulamentadas pelos vários direitos próprios existentes na América ibérica, possuíam um substrato jurídico comum que, por ser pertencente

\footnotetext{
60 Residência tomada pelo ouvidor do crime, João Pedro de Sousa Sequeira Ferraz, pelos serviços prestados pelo bacharel Antônio de Matos e Silva. Lisboa, IV-1759. AHU, caixa 55, doc. 1759.

61 Residência tirada ao juiz de fora João Vieira de Andrade. Lisboa, II-1757. AHU, caixa 51, doc. 51.

62 Seguimos aqui Garriga - Slemian, 2013.

63 Barbas Homem, 2003, p. 585.
} 
ao direito natural, acabavam escapando às disposições políticas. O que nos interessa especialmente destacar aqui é que, debaixo das medidas reformistas feitas com afã de construir um aparato judicial mais uniforme e racionalizado, não se tratou de conceber nenhuma outra forma de garantia de justiça para além destas existentes. Para que se possa fazer uma afirmação categórica deste fato, convém pensar as iniciativas em nome de uma maior centralidade legislativa do rei, e mesmo a tentativa de redução do arbítrio dos magistrados - conforme já vimos acima estar em voga-, se não desde meados do século XVIII, com toda força no seu final, quando se propagandearia a defesa que os mesmos deveriam ser meros aplicadores da lei, não mais seus mais gabaritados intérpretes conforme circunscrito na tradição ${ }^{64}$.

É fato sabido que a profusão legislativa então vivida pelas monarquias ibéricas teria como pano de fundo o projeto de prevalência do direito real (e o pátrio, por extensão) sobre os demais, o que inequivocamente teria certo impacto ${ }^{65}$. No entanto, no que se tratava da prática interna de julgar, da decisão dos magistrados sobre os pleitos, a diminuição de seu arbítrio em nome de uma mais clara e objetiva aplicação da lei careceria de instrumentos normativos para transformação dessa ordem constitutivamente jurisprudencial. O que fica evidente acerca da forma como, em ambas monarquias ibéricas, seria tratada a questão da motivação das sentenças - de explicitar o fundamento jurídico da decisão, ou seja, a base de seu direito. Numa ordem como a de Antigo Regime, menor importância possuía o ato dos juízes declararem os motivos das sentenças, já que a justiça estava constitutivamente localizada na consciência dos seus agentes e não na letra da lei. Ou seja, estava ela centrada na sua capacidade de decidir manejando as regras de interpretação consolidadas pela tradição, respeitando os vários direitos e as leis, observando a manutenção da boa ordem social, obedecendo ao monarca e a Deus: significado, em última instância, do arbítrio, que longe estava de ser uma simples decisão, a princípio, apenas ao seu bel prazer ${ }^{66}$. Daí ser regra geral de direito, como forma de resguardar os próprios agentes da justiça, assegurar-se o segredo das decisões; o que não impossibilitou que a obrigação de explicitar os motivos tenha sido imposta, em alguns casos, devido a circunstâncias e razões específicas. Para nosso caso, enquanto a coroa de Castela (englobando toda a América) seguia tacitamente a regra geral, em Portugal a motivação foi estabelecida desde, pelo menos, o domínio dos Fillipes ${ }^{67}$. Assim estava previsto nas Ordenações que todos os julgadores, fossem ou não letrados, estavam obrigados a declarar:

64 Barbas Homem, 2003, p. 127, discute como é nesse momento que, em Portugal, a “majestas” do príncipe passara a significar, na literatura jurídico-politica, a titularidade da jurisdição suprema, a função legislativa, o poder de criar magistrados, o poder de vender ofícios, o poder de conferir nobreza, o poder de indultar e comutar penas mesmo sem o perdão da parte, o poder de conceder a revisão de sentenças.

65 Wehling, 2004, analisa como o direito real ganharia uma tendência a ter mais vigor nos Acórdãos; Marcos, 2006, analisa como isso fica especialmente evidente para o caso do direito penal.

66 Meccarelli, 1998; Barbas Homem, 2009.

67 Barbas Homem, 2003, pp. 175-177 e p. 256, analisa que havia uma tendência a se defender a importância da vinculação dos juízes à lei para o caso da literatura jurídica portuguesa desde a época moderna; para o caso espanhol, nos outros reinos da coroa de Aragão (Aragão, Catalunha, Valência, Malorca) a motivação havia se imposto legalmente desde o século XVI.Ver: Garriga - Lorente, 1997; Slemian - Payar, 2014. Para comparação entre ambos os casos, GarRiga - SLEMIAN, 2013. 
specificadamente em suas sentenças diffinitivas, assim na primeira instancia, como no caso de appellação, ou aggravo, ou revista, as causas, em que se fundaram a condenar, ou absolver, ou a confirmar, ou revogar ${ }^{68}$.

A justificativa, no entanto, deixava claro que era "para as partes saberem se lhes convém appellar, ou aggravar das sentenças diffinitivas, ou vir con embargos a ellas", além de "os Juizes da mor alçada entenderem melhor os fundamentos, por que os Juizes inferiores se movem a condenar, ou absolver" ${ }^{69}$. Ou seja, a motivação servia para as partes avaliarem se valeria à pena apelar das sentenças, mas também como garantia que a ação dos juízes superiores marcasse as forma de interpretação aos inferiores e depurassem sua responsabilidade. Um espírito de corpo e de reprodução das formas com que se deveriam tratar os casos, muito adequado ao sistema jurisprudencial tradicional do que ao posterior slogan do controle pelas leis.

As medidas ilustradas portuguesas que tiveram por fim a diminuição do espaço de arbítrio judicial em nome da autoridade legislativa do monarca e de uma maior fidelidade às leis, acabariam por reproduzir este padrão, senão aumentariam o espaço do que podemos chamar de incerteza jurídica ${ }^{70}$. $\mathrm{O}$ exemplo mais paradigmático é o da lei de 18 de agosto de 1769 que passaria a ser conhecida como da "boa razão". A norma refletia o espírito da época ao afirmar que há

muitos anos tem sido um dos mais importantes objetos da atenção, e do cuidado das Nações polidas da Europa o de precaverem com sábias providências as interpretações abusivas, que ofendem a Majestade das Leis, desautorizam a reputação dos Magistrados, e tem perplexa a justiça dos Litigantes ${ }^{71}$.

Voltava-se, portanto, contra a tradicional prática de jurisprudência e pregava-se que as "boas razões deve[ria]m ser sempre declaradas", ou seja, estabelecidas as bases que motivavam as sentenças. No entanto, o sentido de novidade em nome de um maior controle, racionalidade e transparência na ação dos juízes que geralmente lhe é atribuído, deve ser matizado. Por um lado, porque ela referendava a prática de motivação já existente na cultura portuguesa, cuja semelhança jamais ocorreu nos territórios da monarquia castelhana, nem mesmo na ilustração. Por outro, porque ela ampliava grandemente o escopo das fontes jurídicas disponíveis, ou seja, seu próprio pluralismo. Isso porque, toda a norma que passasse pelo "filtro" das "luzes", da razão moderna, poderia ser invocada pelos juristas portugueses, inclusive àquelas estrangeiras, diante da inexistência de semelhantes para o território luso, inclusive os "primitivos princípios" que contivessem "verdades essenciais, intrínsecas e inalteráveis" e ligado à "a ética dos mesmos romanos". Previa-se a diminuição dos glosadores medievais (sobretudo de Bártolo e de Acúrsio), do direito canônico e do romano, iden-

68 Ordenações Filipinas, Livro III, Título 66, 7.

69 Ibidem.

70 O alvará de 20/X/1763 (Apud MARCOs, 2006, p. 149) reforçava que as leis deveriam ser escrupulosamente cumpridas sob pena de suspenção dos juízes, pois só ao monarca pertencia a interpretação das leis e alteração das penas nelas comutadas.

71 ColleCÇão... 1829, p. 408. 
tificados com práticas arcaicas e com a tradição antiga da "interpretativo", em nome das leis e usos das "nações iluminadas e polidas" (usus modernus pandectarum).

Cabe admitir que a citada lei, aprovada anos antes da reforma dos Estatudos jurídicos da Universidade de Coimbra (de 1772), criaria um

natural desconcerto da jurisprudência, motivado, desde logo, pela impreparação da magistratura, formada segundo o velho método escolástico-bartolista patrocinado pelos antigos Estatutos da Universidade ${ }^{72}$.

Não só pela existência de uma tradicional prática de interpretação, mas sobretudo pela admissão legal do pluralismo, mantinha-se como fundamental a ação dos jurisprudentes na decodificação da justiça. Dessa forma, sob a categoria de "subsidiário" (e no caso de existência de lacuna na legislação), puderam continuar valendo os outros direitos, desde que incorporados por meio da operação demiúrgica do filtro da "razão", o que permitiria a evidente perpetuação do próprio direito romano ${ }^{73}$. Nesse sentido, por mais que o ambiente da época estivesse marcado pela tentativa de diminuição da incerteza jurídica, através da busca por uma "interpretação autêntica" que diminuísse o espaço de arbítrio judicial, em nome da autoridade do monarca ${ }^{74}$, as reformas ilustradas, nesse quesito, tornaram ainda mais complexa a ação dos magistrados, na mesma chave tradicional. Até onde se sabe, embora não tenha existido uma postura similar à lei da "boa razão", nem à expressão das sentenças pelos tribunais no mundo castelhano (incluindo América), a mesma operação de aumento da potestas régia, em nenhum momento, contribui para o fim do pluralismo jurídico e das formas tradicionais de interpretação.

\section{CONCLUSÕES}

Longe de nós está afirmar que o reformismo ilustrado ibérico não produziu um significativo impacto na vida dos seus domínios ultramarinos. O que se defendeu aqui foi que, no tocante às formas de administração da justiça, houve um visível reforço de concepções e práticas existentes em nome de sua melhor eficácia, mesmo que seja ilusório, e não recomendável, enxergar uma total coerência e linearidade nos projetos e medidas tomadas. Também que a possibilidade de explorar o potencial presente nas perspectivas comparadas e/ou "integradas" de histórias, para este caso, permite-nos

\footnotetext{
72 Marcos, 2006, p. 181.

73 Tal processo seria marcado por tensões, mas a perpetuação do direito romano foi um fato. Veja-se como, a lei que ficara conhecida como da "boa razão" viria a desautorizar uma do ano interior, de 03-XI-1768, que visava restringir a admissibilidade da concessão de revistas (revisão de sentenças) apenas às situações de violação das leis nacionais. Há indícios pela doutrina que estas continuariam a ser dadas "nos casos omissos nas Leis Pátrias" contra as "Leis Romanas, qualificadas justas, e recebidas pelos usos das Nações, ou Legislações destas" (Manuel de Almeida e Sousa, Segundas Linhas.... Apud Barbas Homem, 2003, p. 272, nota 1170; também p. 262). A citada lei de 1768, no entanto, continuaria a marcar a forma como deveriam ser concedidas as revistas. Ver também Marcos, 2006, p. 158.

74 Marcos, 2006, p. 183, discute como a idéia de que apenas o soberano poderia "interpretar, ampliar ou restringir a lei portuguesa" foi repetida na legislação.
} 
pensar em uma unidade dada pela tradição jurídica ibérica que, a despeito das dezenas de especificidades, dotavam de um lastro comum as experiências americanas.

Se as experiências reformistas demonstram algo é que a ordem jurídica tradicional era, em si mesma, constitutivamente limitativa de capacidade de disposição política ao impor uma configuração judicial às práticas de governo e também de justiça, dimensões estas que permaneciam profundamente entrelaçadas. Dessa forma, e especificamente para nosso tema, ela se revelava significativa ao comportar uma certa ontologia do juiz, o qual seguia sendo figura central tanto para sua consecução, como para as formas de garantir seu bom funcionamento, baseadas no controle de seus próprios agentes e na imposição de suas virtudes como pedra de toque para sua maior eficácia (uma justiça de juízes que não de leis) ${ }^{75}$. Nesse sentido, os elementos centrais do d'ancien régime permaneceriam e manteriam suas marcas definidoras mais substanciais: concepção jurisdicional, composição pluralista e configuração jurisprudencial.

Também se pode ver nos reformismos que, no que toca especialmente na chave da justiça, suas experiências tiveram diferentes impactos no que se trata na definição das identidades coloniais (seja permitido que digamos assim). Na América espanhola, é visível como as formas adotadas para sua maior eficácia, baseadas no controle dos cargos pelos crioulos, politizaria a clivagem entre americanos e espanhóis, gerando uma série de tensões na administração da justiça. Na portuguesa, por mais que esse conflito não se tenha feito tão evidente em relação aos magistrados, em função do que já foi apontado acima, é evidente que as medidas ilustradas, de forma geral, acirravam disputas ao proporem uma séria de medidas para bom funcionamento dos seus governos deixando evidente, mais do que nunca, a diferença entre os estatutos dos territórios peninsulares e dos seus domínios. O que se vê claramente no plano jurídico pelos doutrinadores ilustrados portugueses e espanhóis que defenderam a essencialidade das monarquias ibéricas na definição do que seria a nação, do pacto que as faria originalmente legítimas e soberanas realizado há séculos e na Europa ${ }^{76}$. Não à toa, o mesmo D. Rodrigo de Souza Coutinho, evocado desde o início do texto, em escrito contemporâneo ao aqui citado, defenderia, de maneira astuta e política, a "sacrossanta unidade do Império" 77 como forma de colocar todos seus territórios em pé de igualdade. O que certamente se trata de uma outra dimensão desta nossa história.

\section{REFERÊNCIAS BIBLIOGRÁFICAS}

\section{Alonso Romero, Paz}

2010 "La formación de los juristas". En GARriga (coord.), Historia y Constitución: trayectos del constitucionalismo hispano. México. CIDE - Instituto Mora - El Colegio de Michoacán - Hicoes - El Colegio de México, pp. 107-137.

\footnotetext{
75 Lorente, 2006.

76 Portillo VÁldes, 2006; Slemian, 2009.

77 Memória sobre o melhoramento dos domínios de Sua Majestade na América, (1797 ou 1798), em SILVA, 1993 , t. 2, p. 49.
} 
Araujo, Ana Cristina (coord.)

2002 O Marquês de Pombal e a Universidade. Coimbra. Imprensa da Universidade. Barbas Homem, António Pedro

2003 Judex perfectus. Função jurisdicional e estatuto judicial em Portugal 1640-1820. Coimbra. Almedina.

2009 O perfil do juiz na tradição ocidental. Coimbra. Almedina.

BRADING, David

1990 "La España de los Borbones y su imperio americano". En Bethell (ed.), Historia de América Latina. T. II. Barcelona. Crítica. pp. 85-126.

BuRKHOLDER, Mark A.

1972 "From creole to peninsular: the transformation of the Audiencia of Lima". The Hispanic American Historical Review. Durham, n³, vol. 52, pp. 395-415.

Camarinhas, Nuno

2010 Juízes e administração da justiça no Antigo Regime. Portugal e o império colonial, séculos XVII e XVIII. Lisboa. Fundação Calouste Gulbenkian.

2012 “As residências dos cargos de justiça letrada". STumpF - Chaturvedula (orgs.), Cargos e oficios nas monarquias ibéricas. provimento, controlo e venalidade (séculos XVIIXVIII). Lisboa. CHAM, pp. 161-172.

CAMPBEL, Leon G.

1972 "A colonial establishment: creole domination of the Audiencia of Lima during the late Eighteenth Century". Hispanic American Historical Review. Durham, nº 1, vol. 52, pp. 1-25.

CARDIM, Pedro

2008 "La jurisdicción real y su afirmación en la corona portuguesa y sus territorios ultramarinos (siglos XVI-XVIII)". Aranda Pérez - Rodrigues (coords.), De Re Publica Hispaniae. Madrid. Silex, pp. 349-388.

Chaves, Claudia

2013 “A administração fazendária na América portuguesa: a Junta da Real Fazenda e a política fiscal ultramarina nas Minas Gerais”. Almanack. Guarulhos, nº5, pp. 8196. Disponível em: http://www.almanack.unifesp.br/index.php/almanack/article/ viewFile/918/pdf. Acessado em 26/12/2013.

s/d "Arte dos negócios: saberes, práticas e costumes mercantis no Império lusobrasileiro". Actas do Congresso Internacional Espaço Atlântico de Antigo Regime: poderes e sociedades. Disponível em: www.cvc.instituto-camoes.pt/eaar/coloquio/ comunicacoes/claudia_chaves.pdf. Acessado em 02/01/2014.

Chiaramonte, José Carlos (ed.)

1979 Pensamiento de la ilustración iberoamericana, siglo XVIII. Caracas. Bib.Ayacucho.

Clavero, Bartolomé

1997 Happy Constitution. Cultura y lengua constitucionales. Madrid. Trotta.

2012 “Gracia y derecho entre localización, recepción y globalización”. Quaderni fiorentini. Firenze, $n^{\circ} 41$, pp. 675-763.

COLLECÇÂ

1829 --- da Legislação Portugueza desde a última compilação das Ordenações por António Delgado da Silva. Legislação de 1763 a 1774. Lisboa. Typografia Maigrense.

1830 --- da Legislação Portugueza desde a última compilação das Ordenações por António Delgado da Silva. Legislação de 1750 a 1762. Lisboa. Typografia Maigrense. 
ELLIOTT, John

2006 Imperios del mundo atlántico. España y Gran Bretaña en América, 1492-1830. Madrid. Taurus.

Fradera, Josep M.

2005 Colonias para después de un imperio. Barcelona. Bellaterra.

Frate, Paolo Alvazzi del

2005 Giurisprudenzia e référé législatif in Francia nel periodo rivoluzionario e napoleônico. Torino. Giappichelli Editore.

Garriga, Carlos

1997 "La expansión de la visita castellana a Indias: presupuestos, alcance y significado". XI Congreso del Instituto Internacional de Historia del Derecho Indiano. Buenos Aires. Inst. de Inv. de Historia del Derecho, t. 3, pp. 51-79.

2009 “Gobierno y justicia: el gobierno de la justicia”. En LORENTE (coord.). La jurisdicción contencioso-administrativa en España. Una historia de sus orígenes. Madrid. Consejo General del Poder Judicial, pp. 45-113.

2010 “Concepción y aparatos de la justicia: las Reales Audiencias de las Indias”. Cuadernos de Historia, Córdoba. Academia Nacional de Derecho y Ciencias Sociales de Córdoba, nº19. pp. 203- 244.

2013 “Os limites do reformismo bourbônico: a propósito da administração da justiça na América espanhola”. Almanack. Guarulhos, n6, pp. 38-60.

2014 "La politización de la América criolla. (En torno a la Representación mexicana de 1771)". Actas del XVIII Congreso del Instituto Internacional de Historia del Derecho Indiano. Córdoba. Universidad Nacional de Córdoba (en prensa).

Garriga, Carlos - Slemian, Andréa

2013 “Em trajes brasileiros': justiça e constituição na América ibérica (c.1750-1850)". Revista de História. São Paulo, nº169, julho-dezembro, pp. 181-221.

Garriga, Carlos - Lorente, Marta

1997 "El juez y la ley: la motivación de las sentencias (Castilla, 1489-España, 1855)". Anuario de la Facultad de Derecho de la UAM. Madrid. nº1, pp. 97-142.

Gómez GonZÁlez, Inés

2012 ¿"Un medio del control extraordinario? Las visitas particulares y secretas a los magistrados de las Chancillerías y Audiencias castellanas". STUmpF - ChATURVEdula (orgs.), Cargos e oficios nas monarquias ibéricas: provimento, controlo e venalidade (séculos XVII-XVIII). Lisboa. CHAM. pp. 147-159.

GonzÁlez Alonso, Benjamín

1978 "El juicio de residencia en Castilla. I. Origen y evolución hasta 1480". Anuario de Historia del Derecho Español. Madrid, pp. 193-248.

2000 "Los procedimientos de control y exigencia de responsabilidad de los oficiales regios en el Antiguo Régimen". Anuario de la Facultad de Derecho de la UAM. Madrid, no 4, pp. 249-272.

Halperín Donghi, Tulio

1985 Reforma y disolución de los imperios ibéricos 1750-1850. Madrid. Alianza.

HERnÁNDEZ y DÁvalos, Juan E. (ed.)

2007 Colección de documentos para la historia de la guerra de Independencia de México.

México. Universidad Autónoma de México. t.1, nº195. 
Hespanha, Antonio Manuel

1994 As vésperas do Leviathan. Instituições e poder político. Portugal séc. XVII. Coimbra. Almedina.

1998 Panorama histórico da cultura jurídica europeia. Lisboa. Europa-América.

2001 "A constituição do Império português. Revisão de alguns enviesamentos correntes". En Fragoso - Bicalho - Gouvêa (orgs.), O Antigo Regime nos trópicos. Rio de Janeiro. Civilização Brasileira, pp. 163-188.

JAnCsó, István - Pimenta, João Paulo G.

2000 "Peças de um mosaico". En MотA (org.), Viagem incompleta. A experiência brasileira 1500-2000. São Paulo. SENAC, pp. 127-176.

KRYNEN, Jacques

2009 L'idéologie de la magistrature ancienne. Paris. Gallimard.

LEAL CONSELheiro

1842 --- o qual fez D. Duarte. Paris. Typographica de Fain e Thunot.

Lopes, José Reinaldo de L.

2007 “A formação do direito comercial brasileiro". Cadernos Direito GV. São Paulo. FGV, vol. 4, nº 6. Número Monográfico.

LORENTE, Marta (coord.)

2006 De justicia de jueces a justicia de leyes: hacia la España de 1870. Madrid. Consejo General del Poder Judicial.

LYNCH, John

2001 Las revoluciones hispanoamericanas 1808-1826. Ariel. Barcelona.

MAdureira, Nuno Luís

1997 Mercado e privilégios: a indústria portuguesa entre 1750 e 1834. Lisboa. Estampa.

Marcos, Rui Manuel de F.

2006 A legislação pombalina. Alguns aspectos fundamentais. Coimbra. Almedina.

Maxwell, Kenneth

1995 Pombal: Paradox of the enlightenment. Cambridge. Cambridge University Press.

Meccarelli, Massimo

1998 Arbitrium. Un aspetto sistematico degli ordinamenti giuridici in età di diritto comune. Milan. A. Giuffrè.

Monteiro, Nuno Gonçalo

2009a "Pombal's Government: Between Seventeenth-Century Valido and Enlightened Models". En PaQuette (ed.), Enlightened Reform in Southern Europe and its Atlantic Colonies, c. 1750-1830. Farnham-Burlington. Ashgate, pp. 321-338.

2009b “A circulação das elites no império dos Bragança (1640-1808): algumas notas". Teтро. vol. 14, $\mathrm{n}^{\circ} 27$, pp. 65-81.

Novais, Fernando

1986 Portugal e Brasil na crise do Antigo Sistema Colonial (1777-1808). São Paulo. Hucitec.

ORDENAÇÕES MANUELINAS

s/d Lisboa. Fundação Calouste Gulbenkian.

ORDENAÇÕES FiLIPINAS

s/d Lisboa. Fundação Calouste Gulbenkian. 
Paquette, Gabriel (ed.)

2009 Enlightened Reform in Southern Europe and its Atlantic Colonies, c. 1750-1830. Farnham-Burlington. Ashgate.

PEDREIRA, Jorge

1995 Os homens de negócio da praça de Lisboa de Pombal ao Vintismo (1755-1822).

Tese de Doutoramento. FCSH, Univ. Nova de Lisboa.

Pietschmann, Horst

1996 Las reformas borbónicas y el sistema de intendencias en Nueva España. Un estudio político administrativo. México. FCE.

Pimenta, João Paulo

2007 Brasil y las independencias de Hispanoamérica. Castelló de la Plana. Univ. Jaume I.

Portillo VAldés, J. María

2006 Crisis atlántica. Autonomía e independencia en la crisis de la monarquía hispana. Madrid. Marcial Pons.

Ruiz Torres, Pedro

2011 "Los límites del reformismo del siglo XVIII en España”. En Albareda - Miret, (eds.), El nacimiento y la construcción del Estado moderno. Homenaje a Jaume Vicens Vives. Valencia. Universitat de València, pp. 111-150.

SCHWARTz, Stuart

1979 Burocracia e sociedade no Brasil colonial. São Paulo. Perspectiva.

Silva, Andrée Mansuy D. (ed.)

1993 D. Rodrigo de Souza Coutinho. Textos politicos, económicas e financeiros (17831811). Lisboa. Banco de Portugal.

SouzA, Laura de M.

2006 O sol e a sombra: política e administração na América portuguesa do século XVIII. São Paulo. Companhia das Letras.

SLEMIAN, Andréa

2009 Sob o império das leis: constituição e unidade nacional na formação do Brasil (18221834). São Paulo. Hucitec-Fapesp.

Slemian, Andréa - Payar, André

2014 "Las monarquías constitucionales y la justicia, de Cádiz al Nuevo Mundo: el caso de la motivación de las sentencias en el Imperio de Brasil (1822-1850)" (inédito).

SubTiL, José M. L.

2011 Actores, territórios e redes de poder, entre o Antigo Regime e o Liberalismo. Curitiba. Juruá.

STUMPF, Roberta

2012 "Formas de venalidade de ofícios na monarquia portuguesa". En StumpF Chaturvedula (orgs.), Cargos e ofícios nas monarquias ibéricas: provimento, controlo e venalidade (séculos XVII-XVIII). Lisboa. CHAM, pp. 279-298.

VALLEJo, Jesús - VARELLA, Laura Beck

2012 "La cultura del derecho común (siglos XI-XVIII)". En LoRENTE - VALLEJo (coords.), Manual de Historia del Derecho. Valencia. Tirant lo Blanch, pp. 59-100.

Wehling, Arno - Wehling, Maria José

2004 Direito e justiça no Brasil colonial: o Tribunal da Relação do Rio de Janeiro (17511808). Rio de Janeiro - São Paulo - Recife. Renovar.

2012 "Sem embargo da ordenação em contrário". En Gonçalves - Chaves - VenÂncio, Administrando impérios. Belo Horizonte. Fino Traço, pp. 45-60. 